\title{
TOPICS 高分子の薬理活性一生体亡の相互作用
}

\section{Black box モデルと Receptor モデル}

薬理活性と分子構造の関係の解析にコンピニータが 利用されるようになってから久しい。いわゆる定量的 構造活性相関 (QSAR) 解析は 1960 年代より提案, 試行されてきて括り，多くの成功例が市る。この方法 は，一連の同族体の構造変化を反映する置 換 基定数 (Hammet $\sigma, \pi$ Taft Es etc.) と生物活性との関係 を統計処理（重回帰分析）により求めるものである。 この方法では薬物が作用を発現するプロセスを完全に black box として报らが，構造と生物活性の直接的な 関係づけが可能であることが特徵であり，束た利点と なっている。この㹬か飞も black box 的解析法が多 数提案試行されて括り, 文献1 に詳細に述べられてい るので参考にしていただきたい，以上の方法では，方 法論の性質上必然的にコンピュータが利用されるよう になったといってよい，そして，この方法は，一連の 同族体について最適な化合物を求める場合 (lead optimization）飞は強力で岁るが，新規な基本構造を 求める (lead generation) には不十分である。そこ で最近, 分子の性質を, たと党ば理論化学的解析によ り,より詳細㰸討し，また、 コンピュータの能力を より積極的《利用する方法論の確立が各所で試みられ
ている.これが drug-receptor モデルによる構造活 性相関解析2)であり，わ和れも主としてこのモデル 飞基づき種々の解析を行なって拈り，その一例を後で 紹介する。

\section{2. 解析のためのコンピュータシステム}

drug-receptor モデルによる解析で梳, 薬物の作用 発現の引き金性，薬物之生体側の物質 (drug-receptor と呼ぶ）との特異的な結合であると仮定する，そ して，この結合が生じるためには，薬物と receptor が形状に蚛いて鍵と鍵穴のように fit し，また，両者 の表面でェネルギーが安定化さ礼るような相互作用 （静電的相互作用, 水素結合, etc.) が, 数力所で可 能であるような原子（原子団）配置が必要と考光 る.このような条件を見い出すために conformation energy analysis，分子軌道計算，分子 graphics な ぞが多用されることになる，そして，実際に解析を行 なら研究者が，理諭化学要るいはコンピュータの專門 家であるとは限らない，そこでそのような専門家でな くて子容易に目的学達せられるようなコンピュータシ ステムの開発も重要課題の一つとなっている，われわ れもそのようなシステムの確立を試行して和り，まだ 開発途上であるがその有用性を確認している3゙。われ

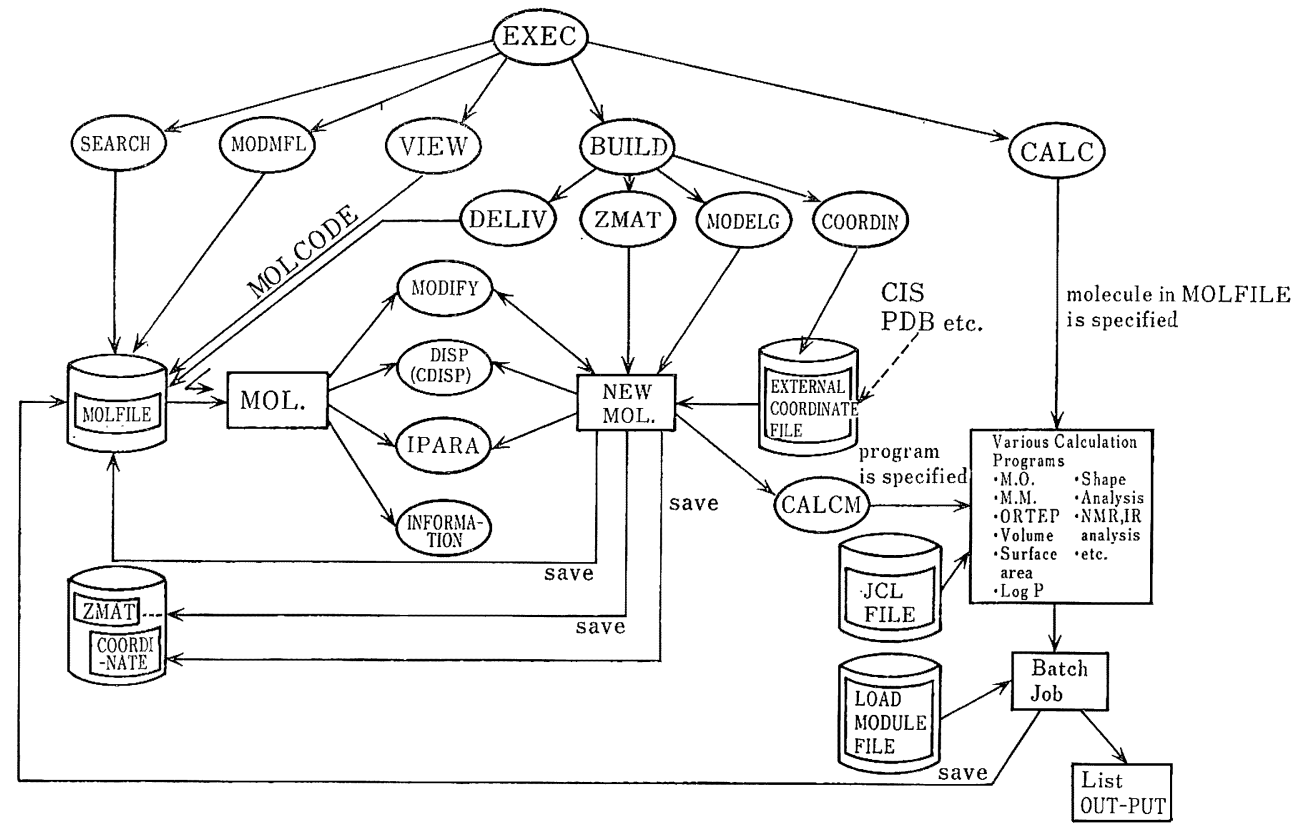

図 1 NAMES (Navigator of Molecular Engıneering/Sience) の概要 

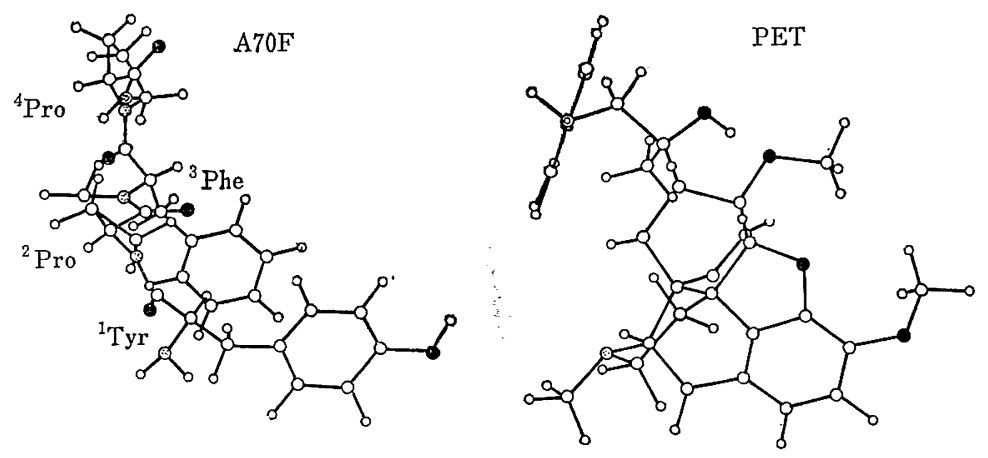

図 2 モルフィセプチンの活性型コンホメーションとモルフィネ (PET)

われの現システム (NAMES) の概要を図 1 亿示す. NAMES により分子の 3 次元構造の組み立て, 修正, その保存, 図型表示, 種々の理論化学計算をきわめて 容易に行なうことができる．操作はすべて対話形式で 行なわれ、システムからの質問に研究者が答党ていく ことにより，目的を達成することができる，プログラ ム稼働のためのコンピュータ知識, あるいは計算のた めの多量のデータの準備やデータの誤りの有無の確認 は一切不要であり, 解析にとって本質的でない労力は 著しく軽減された. 現在, 高機能 3 次元 graphics の 利用あるいは統計的解析システムあるいは化合物管理 システムとの間でのデータの相互利用への配慮などを 中心課題とし,システムの再構築に取り組み中である.

\section{3. 薬理活性とコンホメーションアナリシス}

今回は, 著者の一人 (中馬).と F.A. Momany が 新たに開発したペプチド専用の経験的分子力場計算法 ECEPP83)を使い，鎮痛性ペプチド分子モルフィセ プチンのコンホメーション解析の例( を紹介する。 モ ルフィセプチンは, 牛乳の構成成分 $\beta$-カゼイン中に 含まれる $\beta$-キャソモルフィン類と総称されるぺプ チドの一つで, その1次構造は Tyr-Pro-Phe-Pro$\mathrm{NH}_{2}$ で政る.モルフィセプチンはモルフィネ分子な どと同じく， $\mu$-型受容体ときわめて選択的に結合する ことが報告されている。 そこでモルフィセプチンの活 性型コンホメーションを推定し，それと比較的 rigid なモルフィネ分子などの間比類似性が見い出されるか 否かは,きわめて興味深い問題である。モルフィセプ チンの活性型コンホメーションの解析では, ホず, そ の初期コンホメーションを計算機で約 5,000 個発生さ せ, 同時に ECEPP 83 を用いてェネルギー極小化を 行ない, 約 400 個の安定コンホメーションを得た. 次 に，モルフィセプチンおよびその活性アナログ（Tyr-
D-Pro-Phe-Pro- $\mathrm{NH}_{2}$, Tyr-Pro-Phe-D-Pro- $\mathrm{NH}_{2} な$ ぞ）について先の約 400 個のコンホメーションを初期 コンホメーションとし, さらに, より精密なエネルギ 一極小化を行なった．この段階では, コンホメーショ ナルーエントロピーも考慮した. この結果, モルフィセ プチンおよびそのアナログ分子が共通に取りらるコン

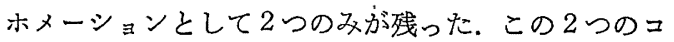
ンホメーションについて,グラフィックディスプレイ によるモルフィネ分子との 3 次元立体構造の比較, 静 電ポテンシャル曲面の比較, 推定相互作用部位の mobility などを考慮した結果, 四 2 左飞示した，A $70 \mathrm{~F}$ と呼ぶコンホメーションを活性型コンホメーションと 推定した。A A $70 \mathrm{~F}$ とモルフィネ分子（図2，PET） とは多くの共通性が見られる.この例は, 目的に応じ た解析・計算の方法・戦略を上手にたてることで, flexible .なペプチド分子でも実験では得難い情報をあ る程度の確度で得られることを示すものである。

\section{文献}

1）a，構造活珄想話会編：薬物の構造活性相関，化 学の領域增刊 122 号, 南江堂 (1979)

b. 構造活性懇話会編：薬物の構造活性相関 II, 化学の領域增刊 136 号, 南江堂 (1982)

2）a. 中馬 寬, 朝永嵉: 薬物の構造活性相関, 化学の領域增刊 136 号, p. 277, 南江堂 (1982) b. 朝永 惊, 中馬 寛: 化学の領域, 36(1), 15 (1982)

3）朝永 嵉, 中馬寛, 熊沢 智: 第 12 回構造活 性シンポジゥム要旨集, p. 297 (1984) 大阪

4) a. H. Chuman, L.A. Shäter, F.A. Momany : Int. J. Peptide. Protein. Res., 24, 233 (1984) b. H. Chuman, F.A. Momany : ibid., 24, 249 (1984)

5) F.A. Momany, H. Chuman : Method in Enzymlogy, in press.

中馬 寛, 朝永 惊 (呉羽化学工業 (株) 技術情報開 発室) 